ARKADIUSZ LEWANDOWSKI

Instytut Politologii UMK

\title{
Republikanizm a współczesne pojmowanie społeczeństwa obywatelskiego
}

7 agadnienie społeczeństwa obywatelskiego jest jedną z kluczowych kweLstii dla opisu zjawisk społecznych transformacji w państwach Europy Środkowej po roku 1989. Obecnie w Polsce mamy do czynienia ze praktyką uznawania społeczeństwa obywatelskiego za wskaźnik rozwoju państwa. W takiej oto atmosferze niewidoczny stał się spór o kształt obywatelskości. Zapomniane zostało, iż jej źródłem jest tradycja republikańska zapoczątkowana w myśli Arystotelesa jako koinonia politike ${ }^{1}$.

Współczesne wznowienie dyskursu o społeczeństwie obywatelskim zostało podjęte $\mathrm{w}$ okresie tworzenia się opozycji antykomunistycznej w latach 70. i 80. XX wieku. Andrew Arato - jeden z jego najbardziej cenionych rzeczników we współczesnych naukach społecznych - stwierdził wprost, iż dyskurs o społeczeństwie obywatelskim został wynaleziony na nowo w Polsce lat siedemdziesiątych ${ }^{2}$. W podobnym tonie wypowiedział się Timothy Garton Ash sugerując, iż historia Europy Środkowo-Wschodniej lat 80. to walka o społeczeństwo obywatelskie prowadzona przez opozycję antysystemową ${ }^{3}$.

D. Pietrzyk-Reeves, Idea społeczeństwa obywatelskiego. Wspótczesna debata i jej źródła, Wrocław 2004, s. 17.

J. Szacki, Wstęp. Powrót idei społeczeństwa obywatelskiego, w: Ani ksiązę, ani kupiec: obywatel, Tenże (red.), Kraków 1997, s. 17.

3 Tamże, s. 16. 
O ile jednak na Zachodzie Europy pojęcie to służy intelektualistom do opisania skomplikowanej rzeczywistości społecznej, o tyle w Europie Środkowej myślenie o samoorganizacji społecznej dopiero się kształtuje, a prężne społeczeństwo obywatelskie uznawane jest jako ideał, do którego dążyć mają rozpoczęte przemiany, związane z przejściem do demokracji oraz gospodarki rynkowej ${ }^{4}$.

Kształt współczesnego społeczeństwa obywatelskiego oparty jest na liberalnej koncepcji, którą próbowali zaadoptować neomarksistowcy krytycy socjalistycznego autorytaryzmu. Unieważnili oni tym ruchem jedno z pojęciowych założeń Marksa, otwierając jednocześnie drogę do postmarksizmu. Arato wymienia tu takich autorów, jak Kołakowski, Mlynar, Vajda i Michnik na Wschodzie, Habermas, Lefort, Bobbio na Zachodzie, Weffort, Cardosso i O’Donnel w Ameryce Łacińskiej. Tkwili oni w bliskiej im tradycji zachodniego neomarksistowskiego dyskursu. Niektórzy odwoływali się do teorii Hegla, młodego Marksa, Gramsciego i Crocego w celu odnowienia dychotomii państwo - społeczeństwo obywatelskie ${ }^{5}$.

Tradycja liberalna nie jest jednak jedyną wizją społeczeństwa obywatelskiego. Wspomniana już przeze mnie arystotelesowska koinonia politike stała się początkiem innej tradycji - republikańskiej. W rzymskiej filozofii jej odpowiednikiem była societas civilis, stanowiąca następnie inspirację dla myślicieli włoskiego renesansu i wczesnonowożytnej myśli politycznej. Głównym spoiwem tejże idei było przekonanie, że człowiek realizuje się poprzez uczestnictwo w życiu publicznym państwa, wspólnoty politycznej, której dobro wymaga podporządkowania prywatnego "ja" domenie tego, co publiczne $^{6}$.

W pracy niniejszej chciałbym zaprezentować i zestawić ze sobą kluczowe założenia różnych koncepcji społeczeństwa obywatelskiego. Moim celem jest ponadto porównanie projektu republikańskiego w kontekście jego stosunku do państwa, społeczeństwa czy też jednostki, z ideą liberalną oraz neomarksistowską wizją Antonio Gramsciego.

\section{Wizja Gramsciego}

W drugiej połowie XX wieku koncepcja społeczeństwa obywatelskiego, szczególnie w Europie Środkowej oraz Ameryce Łacińskiej, opierała się na myśli Antonio Gramsciego. Swoje apogeum osiągnęła w 1967 roku na kongresie gramsciańskim w Cagliari na Sardyni. Organizatorem spotkania był

D. Pietrzyk-Reeves, dz. cyt., s. 10.

E. Górski, Rozważania o społeczeństwie obywatelskim, Warszawa 2003, s. 60.

D. Pietrzyk-Reeves, dz. cyt., s. 17. 
Norberto Bobbio. Oprócz niego swoje przemyślenia prezentowali: Francuz Jasques Texier, Jugosłowianie: Marković, Vranicki, filozof czeski Karel Kosik oraz Węgier Tibor Huszar. Wszyscy zebrani podkreślali wielki wpływ Gramsciego ${ }^{7}$.

Silne oddziaływanie myśli autora Zeszytów więziennych na intelektualistów krajów Europy Środkowej zostało potwierdzone na kolejnym kongresie gramsciańskim w Rzymie w roku $1989^{8}$. Wojciech Pełczyński, opisując przedsięwzięcia pierwszej „Solidarności” w kategoriach gramsciańskich, dostrzegł szereg analogii pomiędzy działaniem polskiej opozycji a teoriami autorstwa Gramsciego'.

Podstawowym pojęciem w myśli Gramsciego była dialektyka społeczeństwa obywatelskiego i społeczeństwa politycznego. W dialektyce tej chodzi o wypracowanie w ramach filozofii praktyki nowej teorii politycznej państwa. Związana jest ona z myślą o zmianach we wszystkich sferach życia społecznego. Jak twierdził sam Gramsci: „poważnym zadaniem teorii i praktyki politycznej jest wypracowanie systemu zasad, który za cel istnienia państwa uznaje jego koniec, to znaczy zniknięcie państwa, czyli wchłonięcie społeczeństwa politycznego przez społeczeństwo obywatelskie"10.

Założyciel Włoskiej Partii Komunistycznej społeczeństwo obywatelskie definiował jako hegemonię polityczną i kulturalną jednej grupy społecznej nad całym społeczeństwem. W hegemoni tej zawierała się społeczna treść państwa związana z konkretnym życiem określonej zbiorowości ludzkiej ${ }^{11}$.

Definicja ta posiada wyraźny heglowski rodowód. Sam Gramsci w tekście, w którym została ona umieszczona, stwierdza, iż należy odróżnić społeczeństwo obywatelskie w rozumieniu jego oraz Hegla od wszystkich doktryn, w których jest ono utożsamiane ze społeczeństwem politycznym. W ten oto sposób jego koncepcja nawiązuje do dorobku myśli liberalnej ${ }^{12}$. Warto jednak zauważyć, że Gramsci idzie o wiele dalej, kreując jako cel społeczeństwa stopniowe poszerzanie wolności, aż do uzyskania zaniku państwa. Idealnym stanem byłoby zatem, aby w stosunkach społecznych ukształtował się zwykły podział pracy niezbędny w przyszłym społeczeństwie zamiast obecnej dekompozycji na rządzących i rządzonych ${ }^{13}$.

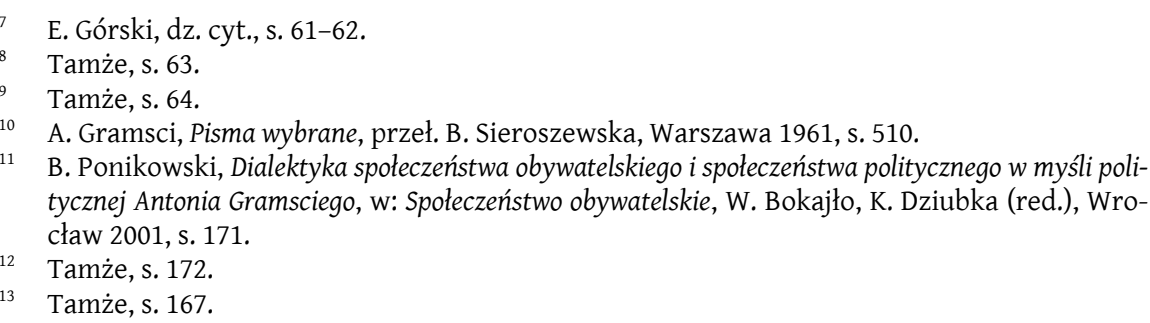




\section{Idea liberalna}

Zapoczątkowana przez Arystotelesa refleksja o aktywności ludzkiej dla dobra wspólnego została zmodyfikowana na przełomie XVII i XVIII wieku. Tradycja liberalna wspólnoty obywatelskiej zastąpiła podejście republikańskie. Proces ten został zapoczątkowany wraz z myślą polityczną Tomasza Hobbesa oraz Jana Locke'a, zaś jego pełne rozwinięcie nastąpiło wraz z filozofią szkockiego oświecenia ${ }^{14}$.

Punktem wyjścia współczesnego (liberalnego) zainteresowania obywatelskością było przeciwstawienie się państwu. W tradycji wolnościowej - jak piszą Cohen oraz Arato - wszystko opiera się na kontrastach: społeczeństwo przeciwko państwu, naród przeciwko państwu, porządek społeczny przeciwko systemowi politycznemu, życie publiczne przeciwko państwu ${ }^{15} . \mathrm{Z}$ perspektywy tej rozwój państwa postrzegany był jako proces destrukcji społeczeństwa, jego „odrodzenie” oznaczać zaś mogło pełne uniezależnienie się od państwa przez stworzenie alternatywnego świata społecznego ${ }^{16}$.

Wewnątrz liberalnej koncepcji społeczeństwa obywatelskiego można doszukać się dwóch źródeł. Hobbes oraz Locke widzieli w tym kontekście umowę społeczną. Hobbes utożsamia społeczeństwo ze społeczeństwem politycznym, przy czym jednak państwo traktuje jako sztuczną osobę prawną ustanowioną za zgodą powołujących ją jednostek ${ }^{17}$. Jest ono zespoleniem rządu i społeczeństwa, którego celem jest strzeżenie uprawnień ludzi przez zagwarantowanie przestrzegania prawa naturalnego. Ujmowanie $\mathrm{w}$ taki sposób obywatelstwa pozwala określić je jako przedpaństwowe, domagające się od państwa gwarancji i wyznaczające mu granice działania ${ }^{18}$.

Odwołanie do innego źródła miało miejsce w filozofii szkockiego oświecenia. Społeczeństwo pojmowane było jako naturalny owoc długiego procesu cywilizacyjnego ${ }^{19}$. Obywatelskość wiąże się - według Adama Fergusona $-\mathrm{z}$ postępem materialnym oraz duchowym, oznacza społeczeństwo cywilizowane ${ }^{20}$.

Zarówno w ujęciu historycznym, jak i dzisiaj, liberalna koncepcja odnosi się sceptycznie do państwa. Społeczeństwem obywatelskim w podejściu negatywnym możemy określić to, co niepaństwowe, co jednak może przy-

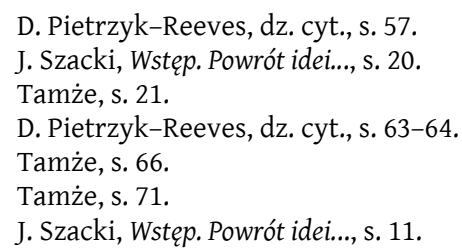


brać trojaką postać: po pierwsze - stanu przedpaństwowego, po drugie antytezy państwa, po trzecie zaś zaniku i końca państwa ${ }^{21}$.

Za istotny wyróżnik społeczeństwa obywatelskiego w rozumieniu nowożytnym przyjmuje się jego niezależność od dyktatu władzy państwowej. Istnienie społeczeństwa obywatelskiego zakłada jednocześnie funkcjonowanie w przestrzeni publicznej wolnej od przymusu państwowego ${ }^{22}$. Współcześnie idea taka realizowana jest na gruncie demokratycznego państwa, w którym coraz częściej życie obywateli realizuje się bez udziału państwa.

\section{Republikańskie społeczeństwo obywatelskie}

Jak już zostało wcześniej zasygnalizowane, liberalna koncepcja obywatelskości była modyfikacją starszego istniejącego już od czasów Arystotelesa republikanizmu. U zarania tradycji republikańskiej społeczeństwo obywatelskie rozumiano jako wspólnotę obywateli. Obywatelstwo kojarzono zaś z przynależnością do wspólnoty oraz aktywnym uczestnictwie w jej życiu politycznym ${ }^{23}$.

W podobny sposób republikanizm traktowali starożytni Rzymianie. Społeczeństwo republikańskie pojmowane było jako sfera rozumu i sprawiedliwości, obywatelskiego uczestnictwa w życiu wspólnoty politycznej. Wspólnota zaś uznawała to samo prawo i współdziałała ze sobą dla ogólnego dobra ${ }^{24}$. Cyceron nadawał jej dodatkowo walorów moralnych ujmując ją jako wspólną sprawę, o którą dba się pospołu, nie jako bezładna gromada, tylko liczne zgromadzenie, jednoczone uznawaniem prawa i pożytków z życia we wspólnocie ${ }^{25}$. W obrębie społeczeństwa obywatelskiego człowiek powinien być kształtowany na świadomego, dobrze poinformowanego obywatela, uczestniczącego w procesach politycznych, reagującego politycznie na problemy kraju ${ }^{26}$.

W nawiązaniu do Arystotelesa interesujące rozważania nad ideą wspólnoty obywatelskiej prezentował Feliks Koneczny. Według autora O wielości cywilizacyj wewnątrz wspólnoty obywatelskiej od człowieka musi zostać wymuszona samodzielność myślenia i działania, ograniczana jedynie przez zasady moralne. Pogląd taki znajdował się w korelacji z koncepcją

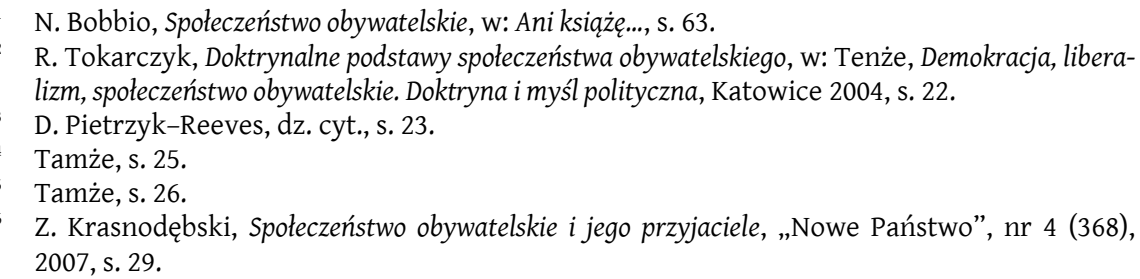


greckiego filozofa, który mówił, iż aby osiągnąć stan doskonałego państwa pożądane byłoby, aby wszyscy obywatele byli ludźmi dobrymi.

Koneczny w swoich rozważaniach o cnotach obywatela wpisuje się w nurt nawiązań do starożytnego republikanizmu obecny wśród współczesnych republikanów. Od Arystotelesa aż po H. Arendt obowiązująca jest teza, iż cnota obywatelska realizuje się przez udział w sferze publicznej ${ }^{27}$. Arystotelesowska klasyczna tradycja republikańska dostrzegła w człowieku przede wszystkim członka zbiorowości. Obywatel jest zobligowany do wyróżniania się szczególnym rodzajem dzielności, czyli cnotą obywatelską lub polityczną. Cnota ta oznaczała sprawność działania na rzecz jakiejś całości politycznej, wiązała się z rozumem praktycznym, była dyspozycją naturalną, na którą oddziałują przyzwyczajenia i obyczaje a następnie rozumowanie i wywody ${ }^{28}$. Podobnie u Konecznego gdzie uwydatniona została etyczna rola obywatela. Cnota, jaką powinna posiadać każda osoba, składa się na zbiorową samoświadomość wspólnego współuczestnictwa w społeczeństwie. Oznacza to występowanie odpowiedzialności w życiu zbiorowym. Ważny jest również fakt, iż dla Konecznego cnoty moralne są równoznaczne cnotom obywatelskim $^{29}$. Obywatelem dlatego mógł być tylko ten, który posiada kulturę czynu, płynącą z wiedzy przyrodzonej oraz nadprzyrodzonej jak również zdatność do działania rozumnego oraz moralnego ${ }^{30}$.

Inny wybitny myśliciel kontynuujący myśl republikańską, Jean Bodin, uznawał, iż najwyższe dobro jednostki i wspólnoty są tym samym, jest to zasadniczy cel, do którego odnosić się powinno prawe rządzenie. o szczęściu państwa decydować miały jednak nie tylko rządy, ale również prawi i mądrzy obywatele odznaczający się cnotami moralnymi i umysłowymi ${ }^{31}$. W takie pojmowanie życia społecznego idealnie wpisuje się nurt komunitarny, który ujmuje społeczeństwo obywatelskie w sposób traktujący jednostki jako podmioty moralne, a sferę polityczną jako obszar angażujący obywateli i nadający kwestiom społecznym szerszy wymiar ${ }^{32}$.

Wydaje się, że cnota obywateli była kluczowym pojęciem dla republikanów. Można ją uznać za fundamentalny termin, który implikuje resztę koncepcji. To dzięki cnocie obywatel może realizować się w państwie, przynosząc korzyść nie tylko dla siebie, ale też dla innych ludzi, jak również dla

27 A. Seligman, Komentarze o społeczeństwie obywatelskim i obywatelskiej cnocie w ostatniej dekadzie XX wieku, w: Ani ksiażę..., s. 178.

28 D. Pietrzyk-Reeves, dz. cyt., s. 21.

29 P. Grabowiec, Model społeczeństwa obywatelskiego w historiozofii Feliksa Konecznego, Wrocław 2000, s. 149.

Tamże, s. 137

D. Pietrzyk-Reeves, dz. cyt., s. 41

Tamże, s. 173 
samego państwa. Będąc dobrym (cnotliwym) sprawia się, że państwo staje się dobre.

Republikanizm zgadza się z liberalizmem, co do celu państwa, jakim powinno być respektowanie i zachowywanie wolności indywidualnych obywateli, lecz inaczej rozumie ową wolność. $W$ tradycji tej jest ona definiowana jako niezależność od obcej władzy, która zniewala nawet, jeśli nie ingeruje w sferę wolności podległego. Dopiero z niej wynika udział w rządach i samorządność. Republikanizm przyjmuje, iż wolność publiczna warunkuje wolność prywatną ${ }^{33}$. Etyka obywatelska - przytaczając za Mickiewiczem - była nie tylko etyką obowiązku wobec wspólnoty narodowej, ale także etyką wolności obywatelskiej w wolnym kraju ${ }^{34}$.

Warto postawić pytanie o to, w jaki sposób została formułowana zależność pomiędzy społeczeństwem a państwem. W teorii wolnościowej władza państwowa jawiła się jako przeciwnik społeczeństwa. Państwo zostało oddzielone od społeczeństwa obywatelskiego. W republikańskiej natomiast państwo jest skutkiem organizowania ludzi w ciało polityczne, a nie w autonomiczny byt pozapaństwowy. Nie występuje tu przeciwstawność między społeczeństwem obywatelskim a państwem. Państwo to emanacja narodu politycznego ${ }^{35}$. Społeczeństwo obywatelskie - wedle założeń koncepcji republikańskiej - można zatem połączyć ze społeczeństwem politycznym poprzez objęcie tym terminem społeczno-politycznych instytucji, do których należy ograniczona w swoich prerogatywach władza lub państwo respektujące rządy prawa oraz system instytucji społecznych ${ }^{36}$.

Koneczny natomiast postulował odrębność społeczeństwa i państwa. Państwo konstytucyjne - uważał - dopełnia społeczeństwo obywatelskie poprzez organizowanie praw obywatelskich, praw własności oraz równości wobec prawa. Twórca historiozoficznej pracy Bizantynizm niemiecki podąża tropem A. de Tocqueville'a, który sugeruje, iż społeczeństwu powinny być nadane takie prawa, które nie ograniczą możliwości dokonywania wolnych decyzji, zgodnych z dobrem osoby oraz wspólnym. Konieczne jest rozdzielenie kompetencji pomiędzy społeczeństwo i państwo tak, aby nie zaistniało przejęcie przez którąś ze stron tych proregatyw, które w sposób naturalny przysługują bądź to państwu bądź społeczeństwu ${ }^{37}$.

Z. Krasnodębski, Demokracja peryferii, Gdańsk 2003, s. 281-282.

Tenże, Drzemka rozsądnych, Kraków 2006, s. 40.

35 Z. Krasnodębski, Społeczeństwo..., s. 29. Krasnodębski używa określenia narodu politycznego jako równorzędnego do społeczeństwa obywatelskiego.

36 P. Broda-Wysocki, Rozwój społeczeństwa obywatelskiego w Polsce, Warszawa 2003, s. 16.

37 P. Grabowiec, dz. cyt., s. 138. 
Sam Koneczny nie antagonizował jednak państwa i wspólnoty, szukał raczej właściwego rozdziału kompetencji. Zaproponował zatem taki typ państwa, który będzie współmierny z naturą społeczeństwa obywatelskiego ${ }^{38}$.

\section{Próba porównania}

Reasumując rozważania o podstawach teoretycznych wspólnoty republikańskiej, chciałbym skonfrontować ją z dwiema pozostałymi koncepcjami na płaszczyźnie stosunku do jednostki jako elementu społeczeństwa, państwa oraz polityki.

Za podstawową wartość w republikaniźmie wyznaje się samowystarczalną wspólnotę polityczną realizującą etyczny cel, jakim jest dobre życie obywateli. Nie występuje tutaj rozróżnienie, które ma miejsce w koncepcji liberalnej, na społeczeństwo polityczne oraz cywilne, a w szerszym znaczeniu na społeczeństwo i państwo ${ }^{39}$. Nie ma także dążenia do destrukcji państwa; przeciwnie - następuje pełna realizacja siebie w jego strukturach.

We wspólnocie politycznej nadrzędne jest dobro wspólne przewyższające dobra partykularne, człowiek zaś spełnia się, realizując swoje cele jako członek wspólnoty troszczący się o jej dobro ${ }^{40}$. Obywatela definiuje się przez pryzmat wspólnoty i jej dobra. Obywatelstwo wiązało się nie z przyrodzonymi prawami jednostki, ale z obowiązkiem troski o to, co publiczne. Sprzyjać miało temu praktykowanie obywatelskich cnót, takich jak sprawiedliwość, męstwo czy też odpowiedzialnośćc ${ }^{41}$. Przestrzeń obywatelstwa odnosiła się do tego, co polityczne: określała horyzont działań obywateli, odnosząc się do tego, co wspólne i co spełnia się w decydowaniu i postanawianiu w służbie publicznej. Członkowie wspólnoty korzystali z przysługujących im praw wraz z państwem, jako jego uczestnicy, a nie przeciwko niemu, jak zakładają teorie nowożytne ${ }^{42}$. W odmienny sposób było także interpretowane dobro. O wiele większą wagę przykładano do zaspokojenia potrzeb jednostki, bez refleksji na temat innych członków społeczeństwa. Realizacja jednostki odbywać się miała w odizolowaniu od państwa.

Inny ważny termin w koncepcji republikańskiej to polityka. Traktowana jako przestrzeń, w której spełnia się najwyższy rodzaj życia oraz właściwe mu cnoty obywatelskie określające godność człowieka ${ }^{43}$. Manfred

Tamże, s. 138.

D. Pietrzyk-Reeves, dz. cyt., s. 51.

Tamże.

Tamże, s. 52.

Tamże.

Tamże, s. 52-53. 
Riedel określił ją (politykę) jako praktyczną wzajemność realizującą się w podwójnym stosunku „mówienia i słuchania, działania i doznawania”"

Polityka - kontynuując rozważania Arystotelesa - powiązana jest z etyką. Celem wspólnoty politycznej jest dobre życie zbiorowości. W największym stopniu przyczyniają się do tego cnoty obywateli postępujących zgodnie z prawem i zasadami słuszności. Zadaniem etycznym polityki było znalezienie takiego ustroju, w którym możliwe byłoby zharmonizowanie różnych aktywności człowieka i wykorzystanie jego działalności przejawiającej się w relacjach z innymi ${ }^{45}$.

Współczesna wizja polityki wobec republikańskiego rozumienia wydaje się wersją okrojoną do minimum. W czasach nowożytnych politykę możemy traktować jako wprowadzanie $\mathrm{w}$ życie konkretnych decyzji. Została więc ona odarta z możliwości poszukiwania najlepszych rozwiązań i swojej etyczności.

\section{Polski republikanizm — „Solidarność”}

W kontekście różnic pomiędzy rozmaitymi tradycjami społeczeństwa obywatelskiego, jakie zostały nakreślone powyżej, ciekawa może wydawać się próba, porównania „Solidarności” ze społeczeństwem republikańskim (podjęta między innymi przez Zdzisława Krasnodębskiego).

Współcześnie w Polsce społeczeństwo obywatelskie definiowane jest jako autonomiczny byt mogący równoważyć władzę państwową, pozwalający jednocześnie społeczeństwu przejawiać swoje interesy i potrzeby oraz wpływać na decyzję publiczne (określenie Wiktora Osiatyńskiego) ${ }^{46}$. W takim tonie definicję formułuje Ewa Nowacka, która za społeczeństwo obywatelskie uważa sferę stosunków i odniesień między jednostkami, grupami społecznymi, które dokonują się poza układem wyznaczonym przez stosunki władzy publicznej. U podstaw społeczeństwa leżą samorzutne inicjatywy społeczne nastawione na cele pozapolityczne. Autorka podkreśla także rozgraniczenie od państwa traktowanego jako społeczeństwo polityczne ${ }^{47}$.

Dominacja nurtu liberalnego ma - według mnie - swoje implikacje w wydarzeniach ostatnich pięćdziesięciu lat na terytorium Polski. Narzucenie władzy komunistycznej z zewnątrz skutkowało - prezentowanym przez większości społeczeństwa - negatywnym stosunkiem do niej. Silny wówczas podział obywatele-państwo został przeniesiony na dzisiejsze społeczeństwo III RP, co umożliwiło powodzenie przeciwstawienia państwa społeczeństwu.

44 Tamże, s. 53.

45 Tamże, s. 54.

46 Z. Krasnodębski, Społeczeństwo..., s. 27.

$47 \quad$ E. Nowacka, Wspótczesna Polska Myśl Polityczna, Kraków 2003, s. 151. 
Dyferencja ta była skuteczniejsza w krajach dawniej rządzonych autorytarnie ze względu na przekonanie o konieczności uwolnienia się od wpływu państwa ${ }^{48}$.

Przeważający nurt nie jest jednak jedynym. Jak już zauważyłem, pojawiła się ciekawa koncepcja Zdzisława Krasnodębskiego. W swoich pracach do idei republikańskiej odwołują się tacy badacze jak Tomasz Żukowski czy też Barbara Fedyszak-Radziejowska.

Andrzej Walicki $W$ trzech patriotyzmach podejmując się ukazania różnic pomiędzy liberalną ideą wolności a koncepcją polskiej szlachty, określa tę drugą jako dążenie do gromadności, stadności wyrażające się nie tylko w zawołaniu „kupą mości panowie”. Demokracja szlachecka miała charakter antyautorytarny, ale na pewno nie indywidualistyczny ${ }^{49}$. Polska, jak pisał Caud Backvis, nie była państwem podobnym do innych, lecz czymś posiadanym wspólnie, o co należało się troszczyć i poczuwać do odpowiedzialności ${ }^{50}$. Spostrzeżenia $\mathrm{w}$ podobnym duchu przedstawił Feliks Koneczny. Fakt, iż Polska nie miała rozbudowanej biurokracji interpretuje on poprzez fenomen republikańskości. Wedle autora polska sztuka rządzenia była oparta na rozbudzaniu ducha obywatelskości i dopiero państwa zaborcze zaszczepiły biurokracje $^{51}$.

Współczesną polską inicjatywą o charakterze republikańskim, wedle Zdzisława Krasnodębskiego, była „Solidarność”. Projekt ten sprowadzał się do budowy demokracji przez naród i dla narodu, rozumianego jako solidarna, związana wartościami, pamięcią, symbolami, ale też otwarta i przyjazna dla obcych wspólnota tradycji, kultury i historii ${ }^{52}$. „Solidarność” kształtowana była przez specyficzne polskie cechy republikanizmu. Wolność oznaczać miała stałą możliwość sprzeciwu wobec decyzji, uwolnienie się od arbitralnej woli komunistów, dzięki uzyskanym możliwościom protestu i kontroli ich poczynan ${ }^{53}$. Wewnątrz związku ceniona była demokracja, ale jeszcze bardziej jednomyślność. Rzecz dla środowiska związkowego typową stanowił wielki patriotyzm lokalny z jednej strony, a niechęć do naruszania lokalnej tożsamości oraz interesów ze strony centrum ${ }^{54}$.

Reasumując rozważania nad „Solidarnością”, warto zauważyć, iż ruch ten jak i inne środowiska opozycyjne w krajach Europy Środkowej, nie były

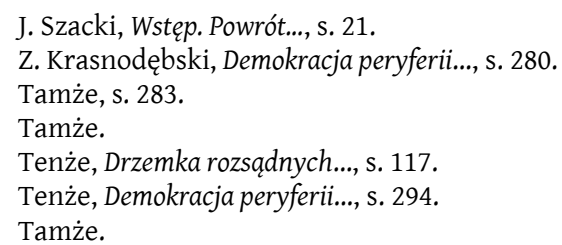


do końca świadome, iż ich działanie znajduje się w obrębie społeczeństwa obywatelskiego. Teoretyzacją zjawiska zajęli się intelektualiści na Zachodzie.

\section{Spostrzeżenia}

Współczesne posługiwanie się definicją społeczeństwa obywatelskiego w kontekście tylko jednej koncepcji w sposób poważny ogranicza istnienie republikańskiej idei, która może być traktowana jako czysta refleksja naukowa. Za główną przyczynę można uznać przedefiniowanie samego pojęcia. Obecnie ideologia społeczeństwa obywatelskiego jest liberalną transformacją marksistowskiej idei obumierania państwa, rozpadu wspólnoty politycznej na wielość koalicji interesów, zastępowania polityki administrowaniem rze$\mathrm{czy}^{55}$.W dążeniu do tak przyjętego społeczeństwa nie ma miejsca na republikanizm.

Innym negatywnym czynnikiem jest fakt, iż współcześnie wolność stała się wolnością indywidualną bez odpowiedzialności i poczucia dobra wspólnego ${ }^{56}$. Obecnie możemy mówić o małej aktywności społeczeństwa w życiu publicznym, jednak stan taki jest wynikiem wyboru społeczeństwa obywatelskiego, które zmierza do oddzielenia społeczeństwa cywilnego od politycznego. Idealnie do opisu sytuacji pasuje opinia Leszka Skiby, mówiąca, iż polski system polityczny widzi nie obywateli, a wyłącznie wyborców. Zmiana wyborcy w obywatela wymaga, by Polacy uzyskali nie tylko instytucjonalne ramy swojego uczestnictwa w życiu publicznym, ale również przekonanie, że wizja dobra, którą uznają jest możliwa do częściowej choćby realizacji w obrębie instytucji państwa ${ }^{57}$.

Spór o kształt społeczeństwa rozgrywa się pomiędzy ideą nowożytną a republikańską. W sporze tym widoczny jest także cień Antonio Gramsciego, ale wobec utopijności likwidacji państwa pomysł ten został zakwestionowany.

Za najważniejszy, a w zasadzie fundamentalny, punkt sporny można uznać relację państwo-społeczeństwo. Jest on o tyle ważny, iż determinuje kształt i funkcje społeczeństwa. Wobec republikańskiej koncepcji państwo jest emanacją społeczeństwa, dobrem wspólnym. W wizji liberałów natomiast jest wrogiem, który przeszkadza w działaniu. W najbardziej radykalnej wersji państwo ma zostać unicestwione, $\mathrm{w}$ innej natomiast oddzielone on społeczeństwa. Tylko republikanizm odwołuje się do formy aktywności spo-

Tenże, Społeczeństwo..., s. 29.

Tenże, Drzemka rozsąnych..., s. 115.

57 L. Skiba, Wyborca czy obywatel, „Nowe Państwo”, nr 1 (369), 2008, s. 21. 
łeczeństwa, która pozwala na współdziałanie państwa i obywateli oraz jednoczesnej ich samorealizacji.

Wobec powyższego rozróżnienia terminy odnoszące się do społeczeństwa jak etyczność, współdziałanie, współodpowiedzialność, wolność, dobro wspólne, czy też naród mogą znaczyć zupełnie, co innego. Niektóre z nich są nieaktualne dla zwolenników nowożytnej idei społeczeństwa cywilnego.

Wybór konkretnego modelu społeczeństwa wpływa także na poziom życia obywateli oraz stopień ich zadowolenia $\mathrm{z}$ działania wewnątrz państwa. Hannah Arendt przeciwstawiła republikanizm demokracji masowej, w której obywatel zastąpiony został prywatną jednostką, a polityczne zasady przekształciły się w społeczne wartości. W takim podejściu duch publiczny zanika na rzecz opinii publicznej, rozum zaś ulega namiętnościom ${ }^{58}$.

Myślę, iż współcześnie bardzo silne oddziaływanie prezentuje koncepcja gramsciańska, jednak republikanizm nie jest już zakończoną historią. W czasie, gdy widać negatywne skutki liberalnego podejścia, podejmowane są próby ożywienia tradycji Arystotelesa. Przyczynili się do tego Quentin Skinner, rekonstruujący neorzymską teorię, czy też John Pocock, analizujący obywatelski humanizm, który nazywa klasycznym republikanizmem ${ }^{59}$.

A R K A D I U S Z L E W A N D O W S K I

Z. Krasnodębski, Demokracja peryferii..., s. 296-297.

59 Tamże. 


\section{The republican idea of civil society}

The main goal of this article is to present the republican idea of civil society and to indicate that nowadays it is frequently being replaced with its liberal concept. The article emphasises the fact that liberal idea of civil society is currently based on outlooks of Antonio Gramsci, a founder of Italian Communist Party. His idea also assumes the action leading to the disappearance of a state.

Furthermore, the author outlines that republican tradition refers to the ideas of Aristotle and concepts which occurred in Ancient Rome. It also relates to the presumption that the main aim of a human being is not to harm their community. According to republican tradition, civil society is an indispensable part of a state and should function within it. Personal rights are subordinated to the common good. In addition to this, republican tradition underlines the importance of ethics. A man was good only by his acts of aid for the community.

Moreover, the article contains a presentation of Feliks Koneczny's ideas. The author claimed that society is supposed to force a human being to think and act independently. What is more, this privilege of independence should be limited only by moral principles. The author also mentions Zdzisław Krasnodębski, his interesting ideas of civil society and Polish model of republicanism, which was accomplished by "Solidarność".

Nowadays a domination of liberal idea is observed. Nevertheless, republican idea of civil society still constitutes a current model of society's activity, particularly due to Quentin Skinner's and John Pocock's outlooks. 